\title{
Perbedaan Kejadian Perdarahan Dan Infeksi Tali Pusat Yang Diikat Dengan Benang Dan Umbilical Cord Clamp.
}

\section{Differences of Bleeding and Umbilical Cord Infection That Has Bound With Yarn And Umbilical Cord Clamp.}

Lisfasiska, Ni Made, Siti Asiyah, S,Kep.Ns.M.Kes (2013).

\begin{abstract}
The use of two different methods of tying the umbilical cord has different consequences for the emergence of the risk of bleeding and infection in the umbilical cord. This research objective is determining the differences of bleeding and umbilical cord infection that has bound with yarn and umbilical cord clamp. Population studied were all babies born in hospitals Pare and RS Gambiran on the date of July 1 to 29, 2013, by using accidental sampling technique obtained sample was 23 respondents consisting of 11 respondents from hospitals Pare and 12 respondents from hospitals Gambiran. The data was collected using observation sheets, the results are then analyzed using fisher exact. The results of analysis shown that $(\mathrm{p}=0,522)>(\alpha=5 \%)$, so that there was no significant difference in the binding of a baby with umbilical cord bleeding events in hospitals and hospitals Gambiran Pare. The results of analysis shown that $(p=0,522)>(\alpha=5 \%)$, so there was no significant differences in binding of the baby's umbilical cord with the incidence of infection in hospitals and hospitals Gambiran Pare. Expected for healthcare institutions that still use nylon thread to tie the umbilical cord, can replace the use of umbilical cord clamp because of a risk of bleeding and infection was lower when care at home.
\end{abstract}

Keywords : Umbilical Cord Binding, Bleeding, Infection

\section{PENDAHULUAN}

\section{Latar Belakang}

Selama kehamilan, tali pusat berfungsi sebagai penghubung kehidupan antara ibu dan anak. Setelah bayi dilahirkan, darah tali pusat yang terdapat pada tali pusat dapat memberikan harapan pada anak dan keluarga lainnya (Cordlife, 2010).

Perawatan tali pusat adalah melakukan pengobatan dan pengikat tali pusat yang menyebabkan pemisahan fisik ibu dengan bayi, dan kemudian tali pusat dirawat dalam keadaan bersih dan terhindar dari infeksi tali pusat. Perawatan tali pusat yang baik dan benar akan menimbulkan dampak positif yaitu tali pusat akan "puput" pada hari ke-5 sampai hari ke-7 tanpa ada komplikasi, sedangkan dampak negative dari perawatan tali pusat yang tidak benar adalah bayi akan mengalami penyakit tetanus neonatorum dan dapat mengakibatkan kematian (Jusmiyati, 2010). Bahaya yang terjadi akibat tidak mengikat tali pusat adalah darah banyak keluar dari ujung tali pusat, meskipun lama-lama akan membeku dan berhenti sendiri dengan risiko terjadi ikterus pada bayi (Alwi, 2011).

Penyebab kematian pada bayi usia < 7 hari terbanyak adalah asfiksia, infeksi neonatorium dan perdarahan. Penyebab terjadinya infeksi neonatorium adalah terjadinya sepsis akibat dari masuknya kuman infeksius kedalam aliran darah diantaranya adalah melalui bekas potongan 
tali pusat. Kondisi ini dapat terjadi karena perawatan tali pusat yang tidak tepat serta pengikatan tali pusat yang tidak tepat. Pada saat ini terdapat 2 metode pengikatan tali pusat, menggunakan benang dan menggunakan umbilical cord clamp. Penggunaan dua metode yang berbeda dalam pengikatan tali pusat memiliki konsekuensi yang berbeda terhadap munculnya resiko perdarahan dan infeksi pada tali pusat. Pada beberapa kasus pengikatan dengan menggunakan benang menimbulkan permasalahan infeksi karena sifat dari benang pengikat yang dapat menjadi media pertumbuhan mikroorganisme, demikian juga dengan konsistensi kekuatan tekanan pada pembuluh darah pada tali pusat sebelum mengalami nekrosis dapat mendorong terhadap terjadinya perdarahan tali pusat.

Perawatan tali pusat yang tidak baik menyebabkan terjadinya infeksi, basah, bernanah, dan berbau yang dapat membahayakan kesehatan bayi (Paisal, 2007). Setiap lima menit, satu orang bayi berumur kurang dari satu bulan meninggal di Indonesia. Kenyataan ini memang sangat memprihatinkan. Angka kematian bayi di Indonesia, meskipun telah berhasil diturunkan, masih tergolong tinggi dibandingkan dengan negara-negara lain di Asia Tenggara. Survei Demografi Kesehatan Indonesia (SDKI) tahun 2007 menunjukkan bahwa angka kematian bayi (berumur di bawah satu tahun atau infant) sebesar 35,28 per seribu kelahiran hidup. Angka ini sudah menurun 29 persen dibandingkan sepuluh tahun sebelumnya (65 per seribu kelahiran hidup). Bila pada tahun 2000 jumlah kelahiran hidup tercatat sebanyak 4.608.000, maka 100.454 diantaranya meninggal pada usia dibawah satu bulan. Sebagian besar dari kematian neonatus muda tersebut terjadi pada bayi yang berumur kurang dari tujuh hari (Kaslam, 2007). Data di RSUD Gambiran Kota Kediri pada tahun 2012 terjadi 136 kejadian sepsis $(7,17 \%)$ pada bayi dari 1897 bayi yang dirawat di rumah sakit.Sedangkan di RSUD Pare Kabupaten Kediri pada tahun 2012 terdapat 31 bayi yang mengalami sepsis, diantaranya 18 bayi lahir di rumah dan 13 bayi karena rujukan. Sedangkan jumlah bayi yang mendapatkan perawatan di rumah sakit karena perdarahan dan lainnya pada tahun 2012 di RSUD Pare Kabupaten Kediri adalah 29 bayi.

Penyebab tingginya angka kematian pada bayi muda $(35,28$ per seribu kelahiran hidup) tersebut diantaranya adalah terjadinya infeksi dan perdarahan. Insiden infeksi dan perdarahan yang terjadi pada bayi muda diantaranya dapat disebabkan oleh model perawatan talipusat yang tidak tepat, khususnya dalam menggunakan model pengikatan talipusat pasca persalinan.

Sesuai dengan standar asuhan persalinan normal (APN) tahun 2004, model pengikatan tali pusat masih meggunakan benang pengikat dan pada tahun 2007 oleh Kementrian Kesehatan RI, diperbarui 
dengan menggunakan umbilical cord clamp. Namun pada kenyataannya tidak semua pemberi layanan persalinan menggunakan umbilical cord clamp untuk melakukan pengikatan pada tali pusat, ada sebagian yang masih menggunakan benang. Dua model pengikatan tali pusat tersebut memiliki konsekuensi yang berbeda pada proses perawatan tali pusat berikutnya.

Penggunaan benang dengan cara perawatan yang tidak tepat dapat menjadi lembab dan menyebabkan berkembangnya mikroorgaisme. Kondisi ini dapat menjadi media yang tepat untuk berkembangnya mikroorganisme yang dapat mendorong terhadap terjadinya infeksi pada sisa potongan tali pusat, pada beberapa kasus infeksi ini menyebar sampai dengan pusat dan terjadi infeksi. Pada kondisi yang berbeda, penggunaan umbilical cord clamp yang cenderung steril dan terbuat dari plastik anti alergen, tidak memberikan dampak berkembang biaknya mikroorganisme yang dapat mendorong terhadap terjadinya infeksi. Konsistensi kekuatan ikatan pada penggunaan benang yang berbeda-beda untuk setiap tenaga penolong persalinan meningkatkan resiko kurangnya kekuatan ikatan pada tali pusat sehingga tidak dapat menekan pembuluh darah secara sempurna. Kondisi ini mendorong terhadap terjadinya perdarahan pada tali pusat. Berbeda dengan penggunaan umbilical cord clamp yang memiliki konsistesi yang tetap untuk menekan pembuluh darah dan mengurangi terhadap terjadinya perdarahan.

Berdasarkan latar belakang tersebut maka peneliti tertarik untuk melaksanakan penelitian dengan judul :

"Perbedaan Kejadian Perdarahan dan Infeksi Tali Pusat yang Diikat dengan Benang dan Umbilical Cord Clamp “

\section{Rumusan Masalah}

Berdasarkan uraian dalam latar belakang diatas, maka permasalahan dalam penelitian ini dapat dirumuskan sebagai berikut :

Apakah ada perbedaan kejadian perdarahan dan infeksi tali pusat yang diikat dengan benang dan umbilical cord clamp?

\section{Tujuan Penelitian}

Tujuan Umum

Mengetahui perbedaan kejadian perdarahan dan infeksi tali pusat yang diikat dengan benang dan umbilical cord clamp .

Tujuan Khusus

1. Mengidentifikasi perdarahan pada tali pusat bayi yang diikat dengan benang.

2. Mengidentifikasi perdarahan pada tali pusat bayi yang diikat dengan umbilical cord clamp.

3. Mengidentifikasi terjadinya infeksi pada tali pusat bayi yang diikat dengan benang.

4. Mengidentifikasi terjadinya infeksi pada tali pusat bayi yang diikat dengan umbilical cord clamp. 
5. Menganalisis perbedaan perdarahan tali pusat yang diikat dengan benang dan umbilical cord clamp.

6. Menganalisis kejadian infeksi tali pusat yang diikat dengan benang dan umbilical cord clamp.

\section{METODE PENELITIAN}

\section{Desain Penelitian}

Jenis penelitian yang digunakan adalah analitik observasional . Dengan desain analitik komparatif.

\section{Populasi, Sampel, dan sampling}

Populasi dalam penelitian ini adalah seluruh bayi baru lahir di RSUD Pare dan RS Gambiran pada tanggal tanggal $1-29$ Juli 2013.

Sampel diambil dari sebagian bayi baru lahir di RSUD Pare dan RS Gambiran yang tersedia pada saat penelitian dan memenuhi kriteria, menggunakan Purposive Sampling.

\section{Tempat Penelitian dan Waktu}

Penelitian dilakukan di RSUD Pare dan RS Gambiran. Penelitian dilaksanakan pada tanggal 1 - 29 Juli 2013.

\section{Instrumen Penelitian}

Instrumen yang dipakai dalam penelitian ini adalah lembar observasi.

\section{Metode Pengumpulan data}

Proses Pengumpulan Data

1. Setelah ijin didapatkan, peneliti memilah pengamatan sbb: Untuk pengikatan tali pusat dengan benang, dilakukan di RS Gambiran. Sedang Metode pengikatan tali pusat dengan Cord Clamp di amati di RS Pare. Memberikan penjelasan tentang tujuan penelitian pada orang tua bayi tentang maksud dari penelitian yang akan dilaksanakan.

2. Peneliti mengobservasi materi yang dipergunakan untuk pengikatan tali pusat. Peneliti melakukan penilaian pengamatan untuk mengetahui terjadi dan tidak terjadinya perdarahan dan infeksi pada bekas potongan tali pusat.

3. Peneliti meneliti masing-masing sampel setiap hari sampai dengan 7 hari post partum, apabila responden telah pulang peneliti melakukan observasi di rumah hingga hari ke 7 .

4. Peneliti melakukan pengolahan data

\section{Metode Pengolahan Dan Analisis Data}

Pengolahan Data dilakukan dengan melakukan editing, pemberian skor, dan koding. Data di analisis dengan Uji ChiSquare

HASIL PENELITIAN \&PEMBAHASAN

Hasil Penelitian

Jenis Kelamin

Tabel 1: Distribusi frekuensi responden berdasarkan jenis kelamin pada bayi baru lahir

\begin{tabular}{|c|l|c|c|}
\hline No & Jenis Kelamin & Frek & \% \\
\hline 1 & Laki-Laki & 12 & $52,2 \%$ \\
\hline 2 & Perempuan & 11 & $47,8 \%$ \\
\hline & Jumlah & 23 & $100 \%$ \\
\hline
\end{tabular}


Berdasarkan tabel 1 dapat diketahui bahwa sebagian besar jenis kelamin responden adalah laki-laki, yaitu 12 responden $(52,2 \%)$.

\section{Material Pengikatan}

Tabel 2: $\quad$ Distribusi frekuensi material pengikat tali pusat pada bayi baru lahir di RSUD Pare dan RSUD Gambiran

Berdasarkan tabel 2 dapat diketahui bahwa sebagian besar responden mendapatkan pengikatan tali pusat menggunakan benang nylon, yaitu 12 responden $(52,2 \%)$.

Kejadian Perdarahan Pada Tali Pusat

\section{Bayi Yang Diikat dengan Benang}

Kejadian perdarahan pada tali pusat bayi yang diikat dengan benang di RSUD Gambiran dapat dilihat pada tabel berikut:

\begin{tabular}{|c|l|c|c|}
\hline No & Perdarahan & Frek & \% \\
\hline 1 & Tidak Terjadi & 11 & $91,7 \%$ \\
\hline 2 & Terjadi & 1 & $4,3 \%$ \\
\hline & Jumlah & 12 & $100 \%$ \\
\hline
\end{tabular}

Berdasarkan tabel 3 dapat diketahui bahwa hampir seluruh responden yang diikat dengan benang tidak terjadi perdarahan, yaitu 12 responden $(91,7 \%)$.

\section{Perdarahan Pada Tali Pusat Bayi Yang Diikat dengan Umbillical Cord Clamp}

Kejadian perdarahan pada tali pusat bayi yang diikat dengan umbillical cord clamp di RS Pare dapat dilihat pada tabel berikut:

Tabel 4: Distribusi frekuensi perdarahan pada tali pusat bayi yang diikat dengan umbillical cord clamp

\begin{tabular}{|c|l|c|c|}
\hline No & Perdarahan & Frek & $\%$ \\
\hline 1 & Tidak Terjadi & 11 & $100,0 \%$ \\
\hline 2 & Terjadi & 0 & $0,0 \%$ \\
\hline & Jumlah & 11 & $100 \%$ \\
\hline
\end{tabular}

Berdasarkan tabel 4 dapat diketahui bahwa seluruh responden yang diikat dengan umbillical cord clamp tidak terjadi perdarahan tali pusat, yaitu 11 responden $(100,0 \%)$.

\section{Kejadian Infeksi Pada Tali Pusat Bayi} Yang Diikat Dengan Benang

\begin{tabular}{|c|c|c|c|}
\hline No & Material Pengikat & Frek & $\%$ \\
\hline 1 & $\begin{array}{l}\text { Benang Nylon } \\
\text { di RSUD Gambiran }\end{array}$ & 12 & $52,2 \%$ \\
\hline 2 & $\begin{array}{l}\text { Umbilical Cord Clamp } \\
\text { di RSUD Pare }\end{array}$ & 11 & $47,8 \%$ \\
\hline & Jumlah & 23 & $100 \%$ \\
\hline
\end{tabular}

Kejadian infeksi pada tali pusat bayi yang diikat dengan benang di RSUD Gambiran dapat dilihat pada tabel berikut:

Tabel 5: Distribusi frekuensi kejadian infeksi pada tali pusat bayi yang diikat dengan benang

\begin{tabular}{|c|c|c|c|}
\hline No & Infeksi & Frek & \% \\
\hline 1 & Tidak Terjadi & 10 & $83,3 \%$ \\
\hline 2 & Terjadi Infeksi & 2 & $16,7 \%$ \\
\hline & & & $100 \%$ \\
\hline
\end{tabular}

Berdasarkan tabel 5 dapat diketahui bahwa sebagian besar responden yamg diikat dengan benang tidak terjadi infeksi pada tali pusat, yaitu 10 responden $(83,3 \%)$.

\section{Kejadian Infeksi Pada Tali Pusat Bayi Yang Diikat Dengan Umbillical Cord Clamp}

Kejadian infeksi pada tali pusat bayi yang diikat dengan Umbillical Cord Clamp di RSUD Pare dapat dilihat pada tabel berikut: 
Tabel 6:Distribusi frekuensi kejadian infeksi pada tali pusat bayi yang diikat dengan umbillical cord clamp

\begin{tabular}{|c|c|c|c|}
\hline No & Infeksi & Frek & $\%$ \\
\hline 1 & $\begin{array}{ll}\text { Tidak } & \text { Terjadi } \\
\text { Infeksi } & \end{array}$ & 11 & $100,0 \%$ \\
\hline 2 & Terjadi Infeksi & 0 & $0,0 \%$ \\
\hline & Jumlah & 11 & $100 \%$ \\
\hline
\end{tabular}

Berdasarkan tabel 6: dapat diketahui bahwa seluruh responden yang diikat dengan umbillical cord clamp tidak terjadi infeksi pada tali pusat, yaitu 11 responden (100\%).

\section{Perbedaan Perdarahan Tali Pusat Yang}

\section{Diikat Dengan Benang Dan Umbilical}

\section{Cord Clamp}

Tabulasi silang antara variabel material pengikat dengan kejadian perdarahan pada bayi baru lahir di RSUD Pare dan RSUD Gambiran adalah sebagai berkut:

Tabel 7: Hasil tabulasi silang antara material pengikat dengan kejadian perdarahan pada bayi baru lahir di RSUD Pare dan RSUD Gambiran

\begin{tabular}{|c|c|c|c|c|c|}
\hline & \multicolumn{2}{|c|}{ Perdarahan } & \multirow[b]{2}{*}{ Total } \\
\hline & & & $\begin{array}{c}\text { Tidak } \\
\text { Terjadi }\end{array}$ & Terjadi & \\
\hline \multirow{4}{*}{$\begin{array}{l}\text { Pengi } \\
\text { kat }\end{array}$} & \multirow[t]{2}{*}{ Benang } & Frek & 11 & 1 & 12 \\
\hline & & $\%$ & $47.8 \%$ & $4.3 \%$ & $52.2 \%$ \\
\hline & \multirow{2}{*}{$\begin{array}{l}\text { Cord } \\
\text { Clamp }\end{array}$} & Frek & 11 & 0 & 11 \\
\hline & & $\%$ & $47.8 \%$ & $.0 \%$ & $47.8 \%$ \\
\hline \multirow{2}{*}{\multicolumn{2}{|c|}{ Total }} & Frek & 22 & 1 & 23 \\
\hline & & $\%$ & $95.7 \%$ & $4.3 \%$ & $100.0 \%$ \\
\hline
\end{tabular}

Berdasarkan tabel 7: dapat diketahui bahwa hampir setengah dari responden yang mendapatkan pengikatan tali pusat menggunakan benang nylon maupun umbilical cord clamp dan tidak terjadi perdarahan.Berdasarkan hasil uji fisher exact didapatkan nilai bahwa $(\mathrm{p}=0,522)>$ $(\alpha=5 \%)$, sehingga dapat disimpulkan bahwa tidak ada perbedaan yang signifikan kejadian perdarahan tali pusat yang diikat dengan benang maupun umbilical cord clamp.

Perbedaan Kejadian Infeksi Tali Pusat Yang Diikat Dengan Benang Dan Umbilical Cord Clamp

Tabulasi silang antara variabel material pengikat dengan kejadian infeksi pada bayi baru lahir di RSUD Pare dan RSUD Gambiran adalah sebagai berkut:

Tabel 5.8 Hasil tabulas silang antara material pengikat dengan kejadian infeksi pada bayi baru lahir di RSUD Pare dan RSUD Gambiran

\begin{tabular}{|l|l|l|c|c|c|}
\hline \multicolumn{2}{|c|}{} & \multicolumn{2}{|c|}{ Infeksi } & \multirow{2}{*}{} \\
\cline { 3 - 6 } \multicolumn{2}{|c|}{} & Tidak & Terjadi & Total \\
\hline \multirow{3}{*}{$\begin{array}{l}\text { Material } \\
\text { Pengikat }\end{array}$} & $\begin{array}{l}\text { Benang } \\
\text { Nylon }\end{array}$ & Frek & 10 & 2 & 12 \\
\cline { 3 - 6 } & $\%$ & $43.5 \%$ & $8.7 \%$ & $52.2 \%$ \\
\cline { 2 - 6 } & $\begin{array}{l}\text { Umbilical } \\
\text { Cord Clamp }\end{array}$ & Frek & 11 & 0 & 11 \\
\cline { 3 - 6 } & $\%$ & $47.8 \%$ & $.0 \%$ & $47.8 \%$ \\
\hline \multirow{2}{*}{ Total } & Frek & 21 & 2 & 23 \\
\cline { 3 - 6 } & $\%$ & $91.3 \%$ & $8.7 \%$ & $\begin{array}{c}100.0 \\
\%\end{array}$ \\
\hline
\end{tabular}

Berdasarkan tabel 5.8 dapat diketahui bahwa sebagian besar responden yang mendapatkan pengikatan tali pusat menggunakan umbilical cord clamp tidak mengalami infeksi.

Berdasarkan hasil uji fisher exact didapatkan nilai bahwa $(\mathrm{p}=0,522)>(\alpha=5 \%)$, sehingga dapat disimpulkan bahwa tidak ada 
perbedaan yang signifikan kejadian infeksi tali pusat yang diikat dengan benang atau umbilical cord clamp di RSUD Pare dan RSUD Gambiran.

\section{Pembahasan}

\section{Kejadian Perdarahan Pada Tali Pusat}

\section{Bayi Yang Diikat Dengan Benang}

Berdasarkan tabel 3 dan 4 terdapat hasil hampir seluruh responden yang tali pusatnya diikat dengan benang 11 responden $(91,7 \%)$ tidak terjadi perdarahan dan 1 responden $(4,3 \%)$ terjadi perdarahan.

Salah satu material yang dapat dipergunakan untuk mengikat tali pusat adalah benang nylon karena sifatnya yang liat dan lentur. Material yang dipergunakan untuk membuat benang nylon adalah polyamida. Sifat yang dimiliki nylon adalah bersifat keras, berwarna cream, sedikit tembus cahaya (Suryadi, 2009).

Hasil penelitian menunjukkan bahwa pada pengikatan dengan menggunakan benang nylon, mayoritas dari responden tidak mengalami perdarahan, namun masih terdapat responden yang mengalami perdarahan. Hasil penelitian ini menunjukkan bahwa penggunaan benang nylon untuk mengikat tali pusat efektif untuk mencegah perdarahan yang terjadi pada tali pusat. Pengikatan dengan menggunakan tali pusat walaupun dapat dikatakan efektif tetapi tetap memiliki resiko perdarahan, hal ini terbukti dari hasil penelitian yang menunjukkan adanya perdarahan pada 1 responden. Berdasarkan hasil pengamatan, perdarahan terjadi pada responden nomor 3, dimana perdarahan terjadi pada hari ketiga ketika dilakukan perawatan di rumah. Kondisi ini menunjukkan bahwa perdarahan yang terjadi disebabkan karena seiring perjalanan waktu tali pusat bayi semakin menyusut dan dengan ikatan benang yang tetap kemungkinan dapat menyebabkan terjadinya perdarahan tali pusat. Menurut Santosa (2008), salah satu penyebab terjadinya perdarahan tali pusat adalah berkurangnya jepitan pada tali pusat.

\section{Kejadian Perdarahan Pada Tali Pusat Bayi Yang Diikat Dengan Umbillical Cord Clamp}

Berdasarkan tabel 5.4 terdapat seluruh responden yang tali pusatnya diikat dengan umbillical cord clamp tidak mengalami perdarahan yaitu 11 responden $(100 \%)$.

Umbilical cord clamp memiliki bentuk seperti rahang dengan gerigi yang saling bertautan sehingga dapat mengikat tali pusat dengan kuat dan memiliki kekuatan penjepitnya yang standar yaitu adalah 5 psi (Onemed, 2007). Menurut Mujiarto (2004) kelebihan material pengikatan tali pusat meliputi: tidak menyerap air, memiliki impact strength (daya jepit) yang kuat, memiliki daya jepit standar, tidak menimbulkan alergi.

Hasil penelitian ini menunjukkan bahwa pengikatan tali pusat dengan menggunakan umbillical cord clamp sangat efektif untuk mencegah terjadinya 
perdarahan. Kondisi ini disebabkan karena sifat pengikatan tali pusat dengan menggunakan umbilcal cord clamp memiliki sifat standar dan sama untuk setiap produk yang dikeluarkan yaitu dengan tekanan sebesar 5 psi pada tali pusat sehingga dapat mencegah terjadinya perdarahan. Pada perawatan di rumah sakit oleh tenaga kesehatan maupun perawatan di rumah yang dilakukan oleh ibu yang awam tentang perawatan tali pusat ternyata tidak mempengaruhi kekuatan pengikatan tali pusat yang menggunakan umbillical cord clamp, sehingga terjadinya perdarahan dapat dicegah.

Kejadian Infeksi Pada Tali Pusat Bayi Yang Diikat Dengan Benang

Berdasarkan tabel 5.5 terdapat hasil sebagian besar responden yang tali pusatnya diikat dengan benang yaitu 10 responden $(83,3 \%)$ tidak mengalami infeksi dan 2 responden $(16,7 \%)$ mengalami infeksi.

Nylon adalah istilah yang digunakan terhadap poliamida yang mempunyai sifatsifat dapat dibentuk serat, film dan plastic. Struktur nylon ditunjukkan oleh gugus amida yang berkaitan dengan unit hidrokarbon ulangan yang panjangnya berbeda-beda dalam suatu polimer. Sifat yang dimiliki nylon adalah higroskopis, oleh karena itu perlu dikeringkan sebelum dipakai, karena sifat mekanis maupun elektriknya dipengaruhi juga oleh kelembaban relatif dari atmosfir (Suryadi, 2009).

Hasil penelitian menunjukkan bahwa penggunaan nylon sebenarnya dapat efektif mencegah terjadinya infeksi, kondisi ini terbukti dengan hasil penelitian yang menunjukkan jumlah responden yang mengalami infeksi cukup sedikit yaitu hanya $4,21 \%$ dari seluruh responden, namun penggunaan benang nylon tetap memberikan resiko infeksi jika perawatannya tidak tepat. Pada saat dilakukan perawatan di rumah sakit (hari pertama dan kedua) seluruh responden tidak menunjukkan tanda-tanda infeksi, namun setelah dilakukan perawatan di rumah baru ada responden yang menunjukkan tanda-tanda infeksi. Berdasarkan lampiran 5 tentang tabulasi data diketahui bahwa tanda-tanda infeksi muncul pada responden 25 pada hari kelima menunjukkan peningkatan suhu tubuh, responden nomor 2 yang menunjukkan kemerahan di sekitar tali pusat pada hari kelima, responden nomor 6 yang menunjukkan kemerahan pada hari kelima dan keenam. Hal ini menunjukkan bahwa tanda-tanda infeksi muncul pada saat dilakukan perawatan di rumah. Salah satu penyebab infeksi adalah proses pengeringan sekitar tali pusat yang kurang sempurna dan tali pusat terkena air menyebabkan pengikat yaitu benang nylon menyerap air, karena ada material organik dan air maka dapat dijadikan sebagai lokasi 
koloni dari mikroorganisme yang memicu terjadinya infeksi.

\section{Kejadian Infeksi Pada Tali Pusat Bayi Yang Diikat Dengan Umbillical Cord Clamp}

Berdasarkan tabel 5.6 terdapat hasil seluruh responden yang tali pusatnya diikat dengan umbillical cord clamp tidak mengalami infeksi yaitu 11 responden (100\%).

Bahan yang dipergunakan dalam pembuatan umbilical cord clamp adalah polycarbonate.

Polycarbonate

(polikarbonat) merupakan engineering plastic yang dibuat dari reaksi kondensasi bisphenol A

dengan fosgen (phosgene) dalam media alkali. Polikarbonat mempunyai sifat-sifat : jernih seperti air, impact strengthnya sangat bagus, ketahanan terhadap pengaruh cuaca bagus, suhu penggunaannya tinggi, mudah diproses, flameabilitasnya rendah, keras dan memiliki finishing sangat halus serta licin pada permukaannya. Sifat dari polycarbonate adalah tidak menyerap air (anti higroskopis) sehingga sesuai jika dipergunakan untuk alat medis yang penggunaannya cenderung pada tempat yang berair (Mujiarto, 2005).

Hasil penelitian menunjukkan bahwa tidak ada responden yang mengalami infeksi pada penggunaan umbillical cord clamp untuk mengikat tali pusat.
Penggunaan umbilical cord clamp yang terbuat dari polycarbonate yang tidak menyerap air sehingga resiko terjadinya infeksi dapat diminimalkan jika didukung oleh cara perawatan tali pusat yang benar. Hasil penelitian ini menunjukkan bahwa dalam melakukan perawatan tali pusat di rumah apabila terjadi kesalahan yang tidak fatal misalnya proses pengeringan yang tidak sempurna setelah bayi dimandikan tidak menyebabkan terjadinya infeksi karena umbilical cord clamp yang terbuat dari polycarbonate yang tidak menyerap air.

\section{Perbedaaan Perdarahan Tali Pusat Yang Diikat Dengan Benang Dan Umbilical Cord Clamp.}

Hasil analisa data perbedaaan tali pusat dengan kejadian perdarahan di RSUD Pare dan RSUD Gambiran berdasarkan hasil uji fisher exact didapatkan nilai bahwa ( $\mathrm{p}=$ $0,522)>(\alpha=5 \%)$ sehingga dapat disimpulkan bahwa tidak ada perbedaan signifikan antara kejadian perdarahan tali pusat yang diikat dengan benang dengan umbilical cord clamp di RSUD Pare dan RSUD Gambiran.

Umbilical cord clamp memiliki bentuk seperti rahang dengan gerigi yang saling bertautan, didistribusikan dalam kondisi yang steril dan penggunaannya adalah dispossable atau sekali pakai. Bahan yang dipergunakan halus dan tidak menimbulkan 
iritasi pada kulit bayi. Kekuatan penjepitnya adalah 5 psi (Onemed, 2007).

Berdasarkan hasil analisis menunjukkan tidak adanya perbedaan yang signifikan atas terjadinya perdarahan pada penggunaan benang nylon dan umbilical cord clamp sebagai pengikat tali pusat. Namun dari hasil penelitian juga diketahui bahwa pada penggunaan umbilical cord clamp tidak ada responden yang mengalami perdarahan namun pada penggunaan benang nylon ada responden yang mengalami perdarahan. Kondisi ini menunjukkan secara umum penggunaan benang nylon dan umbilical cord clamp sebenarnya tidak memiliki perbedaan yang berarti namun karena proses perawatan yang berbeda maka muncul permasalahan yang berbeda pula, dimana dalam penggunaan umbilical cord clamp tidak mengalami perubahan karena perawatan namun penggunaan benang nylon dapat menyebabkan terjadinya perubahan karena proses perawatan yang tidak tepat. Berdasarkan kondisi ini dapat diketahui bahwa penggunaan umbilical cord clamp dengan benang nylon tidak memberikan efek yang berarti terhadap perdarahan ketika perawatan tali pusat dilakukan oleh tenaga kesehatan yang telah terampil, namun pada perawatan yang dilakukan oleh masyarakat umum penggunaan benang nylon menjadi lebih beresiko.

\section{Perbedaan Kejadian Infeksi Tali Pusat Yang Diikat Dengan Benang Dan Umbilical Cord Clamp.}

Hasil analisa data perbedaaan tali pusat dengan kejadian infeksi di RSUD Pare dan RSUD Gambiran berdasarkan hasil fisher exact didapatkan nilai bahwa (p $=0,522)>(\alpha=5 \%)$, sehingga dapat disimpulkan bahwa tidak ada perbedaan yang signifikan antara kejadian infeksi tali pusat yang diikat dengan benang atau umbilical cord clamp di RSUD Pare dan RSUD Gambiran.

Masuknya kuman ke dalam tubuh bayi dapat terjadi karena perawatan tali pusat yang tidak tepat serta pengikatan tali pusat yang tidak tepat. Pada saat ini terdapat 2 metode pengikatan tali pusat, menggunakan benang dan menggunakan umbilical cord clamp. Penggunaan dua metode yang berbeda dalam pengikatan tali pusat memiliki konsekuensi yang berbeda terhadap munculnya resiko perdarahan dan infeksi pada tali pusat. Pada beberapa kasus pengikatan dengan menggunakan benang menimbulkan permasalahan infeksi karena sifat dari benang pengikat yang dapat menjadi media pertumbuhan mikroorganisme, demikian juga dengan konsistensi kekuatan tekanan pada pembuluh darah pada tali pusat sebelum nekrosis dapat menyebabkan perdarahan tali pusat (Cordlife, 2010).

Hasil analisis menunjukkan tidak ada perbedaan yang signifikan dari penggunaan 
media pengikatan tali pusat walaupun ada perbedaan perbedaannya sedikit sekali, pada satu sisi pengikatan tali pusat menggunakan umbilical cord clamp tidak memberikan resiko infeksi namun penggunaan benang nylon dapat menyebabkan terjadinya infeksi. Hal ini tidak dapat dilepaskan dari proses perawatan. Berdasarkan hasil penelitian terlihat bahwa infeksi terjadi ketika bayi telah dibawa pulang dan bukan saat terjadi di rumah sakt, artinya sebenarnya kedua metode pengikatan tali pusat tersebut tidak memberikan pengaruh terhadap terjadinya infeksi ketika proses perawatan tali pusat dilakukan oleh tenaga yang terampil, tetapi ketika perawatan tali pusat dilakukan oleh tenaga yang tidak terampil yaitu orang tua bayi, maka baru memuncukan resiko infeksi pada penggunaan benang nylon. Benang nylon memiliki sifat higroskopis yaitu kemampuan suatu zat untuk menyerap molekul air dari lingkungannya baik melalui absorbsi atau adsorpsi. Suatu zat disebut higroskopis jika zat itu mempunyai kemampuan menyerap molekul air yang baik. Untuk penggunaan dalam pengikatan tali pusat, hal ini dapat menyebabkan terjadinya pertumbuhan mikroorganisme pada tali pengikat yang berdampak pada terjadinya infeksi ketika proses pengeringan tali pusat dan sekitarnya tidak sempurna atau ketika bayi ditempatkan pada lingkungan yang lembab. Hal ini berarti kedua metode pengikatan tali pusat tidak menimbulkan resiko infeksi ketika perawatan dilakukan oleh tenaga terampil, tetapi penggunaan benang nylon memberikan resiko infeksi ketika perawatan dilakukan oleh orang awam.

\section{Keterbatasan Penelitian}

Dalam penelitian ini dijumpai beberapa keterbatasan pada proses pengumpulan data yaitu :

1. Pada observasi perdarahan dan infeksi tali pusat setelah dalam perawatan di rumah hanya dilakukan sehari sekali sehingga ada kemungkinan perdarahan yang tidak diketahui oleh peneliti di luar waktu observasi.

2. Variabel perancu dalam penelitian ini khususnya terkait dengan cara perawatan tali pusat di rumah tidak dijadikan pertimbangan pada proses analisis sehingga dapat menimbulkan bias.

\section{KESIMPULAN DAN SARAN}

\section{Kesimpulan}

1. Hampir seluruh tali pusat bayi yang diikat dengan benang mengalami perdarahan.

2. Tali pusat bayi yang diikat dengan umbillical cord clamp tidak ada yang mengalami perdarahan.

3. Sebagian kecil tali pusat bayi yang diikat dengan benang mengalami infeksi. 
4. Tali pusat bayi yang diikat dengan umbillical cord clamp tidak ada yang mengalami infeksi.

5. Tidak ada perbedaan yang signifikan kejadian perdarahan antara tali pusat yang diikat dengan benang atau umbilical cord clamp di RSUD Pare dan RSUD Gambiran.

6. Tidak ada perbedaan yang signifikan kejadian infeksi pada tali pusat yang diikat benang dengan umbilical cord clamp di RSUD Pare dan RSUD Gambiran.

\section{Saran}

1. Bagi Institusi Kesehatan

Diharapkan bagi institusi kesehatan yang masih menggunakan benang nylon untuk mengikat tali pusat, dapat menggantinya dengan menggunakan umbilical cord clamp karena memberikan potensi terjadinya perdarahan dan infeksi yang lebih rendah ketika dilakukan perawatan di rumah.

2. Bagi Institusi Pendidikan

Diharapkan dapat mengembangkan penelitian tentang pengaruh penggunaan material kebidanan sehingga dapat dijadikan sebagai bukti empiris guna pengambilan kebijakan bagi pihak yang berwenang secara tepat.

3. Bagi Peneliti Selanjutnya
Diharapkan dapat mengembangkan dan menyempurnakan penelitian ini dengan melakukan pengkajian yang lebih mendalam melalui eliminasi terhadap variabel perancu yaitu perawatan tali pusat yang tidak

\section{DAFTAR PUSTAKA}

Alwi, Qomariah. 2010.Budaya Persalinan Suku Amungme dan Suku Kamoro Papua. Jakarta : Jurnal Kedokteran Trisakti Vol. 23 No.4

APN, Depkes RI. 2008. Asuhan Persalinan Normal. Jakarta: JNPK-KR.

Azis Alimul H, 2003. Metode Penelitian Keperawatan dan teknik Analisa Data, Penerbit

\section{Metode} Penelitian Kebidanan dan Teknik Analisa Data. Jakarta : Salemba Medika

Bobak, M. Irene, at all. 2005. Buku Ajar Keperawatan Maternitas, edisi 4.Jakarta : EGC . 2008. Buku Ajar keperawatan Maternitas Edisi 5. Jakarta. EGC

Cordlife. 2010. Tentang Sel Punca. http://www.cordlife.co.id/in/bankdarah-tali-pusat/tentang-darah-talipusat.

Fraser, Copper. 2008. Buku Ajar Kebidanan. Jakarta : EGC.

Hamilton, Marry. 2006. Ilmu Keperawatan Maternitas. Jakarta : EGC.

Hayati, N. 2009. Merawat tali pusat, http://repository.usu.ac.id/bitstream /123456789/27207/4/Chapter\%20II.p $d f$. 
Haws, Paulette S. 2008. Asuhan Neonatus Rujukan Cepat. Jakarta : EGC.

Jusmiyati. 2010. Efektifitas Pendidikan Kesehatan Menggunakan Media Audiovisal terhadap Tingkat Pengetahuan dan Kemampuan Ibu Merawat Bayi Baru Lahir. Palembang : Fakultas Kedokteran Universitas Sriwijaya.

Kaslam, Pacho. 2007. Ketahui Penyebab Bayi Meninggal di Masa Neonatus. http://life.viva.co.id/news/read/39379 3-ketahui-penyebab-bayi-meninggaldi-masa-neonatus

Kementerian Kesehatan RI. 2007. Informasi Seputar Bayi Baru Lahir. Jakarta : Direktorat Bina Kesehatan Anak Kementrian Kesehatan RI

Manuaba. 2010. Ilmu Kebidanan dan Keluarga Berencana Untuk Pendidikan Bidan. Jakarta : EGC.

Musbikin, Imam. 2006. Panduan Bagi Ibu Hamil dan Melahirkan. Jakarta : Mitra Pustaka.

Mujiarto, Iman. 2005. Sifat Dan Karakteristik Material Plastik Dan Bahan Aditif. Jurnal Traksi Vol.3 No.2.

Notoatmojo, Soekidjo. 2005. Metode Penelitian Kesehatan. Edisi Revisi. Jakarta. Rineka Cipta.

Penelitian Kesehatan. Jakarta : Rineka Cipta.

Noval, Andika. 2009. Faktor-Faktor Yang Mempengaruhi Ketrampilan Ibu Nifas dalam Melaksanakan Perawatan Bayi Baru Lahir. http://images.puspitastat.multiply.mult iplycontent.com

Nursalam. 2008. Konsep dan Penerapan Metodologi Penelitian Ilmu Keperawatan. Jakarta : Salemba Medika.
Onemed. 2007. Umbilical Cord Clamp. http://onemedhealthcare.com /products.php? ID $=72 \& \mathrm{cID}=7 \& \mathrm{scID}=$ \&action $=$ detail

Prawirohardjo, Sarwono. 2006. Buku Acuan Nasional Asuhan Maternal dan Perinatal. Jakarta : YBSP.

2007. Ilmu

Kebidanan. Jakarta : YBSP.

Simkin, Whalley \& Keppler. 2008. Panduan Praktis Bagi Calon Ibu: Kehamilan dan Persalinan. Jakarta : PT. Bhuana Ilmu Populer

Sodikin, et al. 2009. Buku Saku Perawatan Tali Pusat, EGC: Jakarta

Suharsimi, Arikunto. 2006. Prosedur Penelitian. Jakarta : Rinneka Cipta.

Sudarti, A. 2003. Asuhan Kebidanan Neonatus Risiko Tinggi dan Kegawatan. Jakarta: Medical Book.

Suryadi. 2009. Teori Dasar Ilmu Material. Jakarta: Erlangga.

Walsh,B Patre. 2007. Buku Ajar Kebidanan Komunitas. Jakarta : EGC

Wibowo, Aji. 2008. Perawatan Tali Pusat. http://digilib.unimus.ac.id /download.php?id=9372 